KOLOM ILMIAH

Social Humaniora

\title{
POLA KOMUNIKASI POLITIK KPU KABUPATEN SUMBAWA DALAM MENGHADAPI PILKADA BUPATI DAN WAKIL BUPATI TAHUN 2015 (Studi Kasus : Kampanye KPU Kabupaten Sumbawa dalam Upaya Menciptakan Pilkada Bupati dan Wakil Bupati Kabupaten Sumbawa yang Kondusif Tahun 2015)
}

\author{
Muhammad Rifki Rizqiyana', ${ }^{1}$ Abbyzar Aggasi ${ }^{2}$ \\ ${ }^{12}$ Fakultas Ilmu Komunikasi, Universitas Teknologi Sumbawa \\ Email: mrifkirizqiyana08@gmail.com, abbyzaraggasi18@gmail.com
}

\begin{abstract}
ABSTRAK
Diterima:

Januaru 2019

Diterbitkan:

Februari 2019

Kata Kunci:

Komunikasi

Politik, KPU,

PIlkada,

Kampanye

Penelitian ini bertujuan untuk mengetahui pola komunikasi politik yang diterapkan oleh KPU Kabupaten Sumbawa dalam menghadapi Pilkada Bupati dan Wakil Bupati Kabupaten Sumbawa tahun 2015, sehingga pelaksanaan kampanye oleh KPU Kabupaten Sumbawa berjalan dengan kondusif. Permasalahan yang dikaji adalah bagaimana pola komunikasi politik KPU Kabupaten Sumbawa dalam upaya menciptakan penyelenggaraan kampanye oleh KPU Kabupaten Sumbawa dalam menghadapi Pilkada Bupati dan Wakil Bupati yang kondusif tahun 2015. Hal yang digunakan dalam penelitian ini untuk menjawab permasalahan tersebut peneliti menggunakan teori pola komunikasi politik menurut Onong Uchdjana Effendi. Proses pengumpulan data dalam penelitian ini adalah dengan observasi non-participant, in-depth interview, dan dokumentasi, selain itu proses analisis data dengan cara, reduksi, men-display data, verifikasi dan kesimpulan. Oleh karena itu penelitian ini termasuk dalam penelitian kualitatif deskriptif, hasil dari penelitian ini adalah pola komunikasi politik satu arah, pola komunikasi politik dua arah, dan pola komunikasi politik multi arah sebagaimana menurut Onong Uchdjana Effendi digunakan oleh KPU Kabupaten Sumbawa dalam berkampanye upaya menciptakan Pilkada yang kondusif tahun 2015, adapun pola komunikasi budaya KPU Kabupaten Sumbawa yang diterapkan dalam pelaksanaan debat publik berlangsung, sehingga menjadi ikon dan inovasi terbaru yang diselenggarakan oleh KPU Kabupaten Sumbawa dalam berkampanye pada Pilkada Bupati dan Wakil Bupati Kabupaten Sumbawa yang berjalan kondusif tahun 2015, secara verbal maupun secara non verbal.
\end{abstract}

\section{PENDAHULUAN}

Dengan berkomunikasi, manusia dapat memenuhi kebutuhan kesehariannya, mendapatkan apa yang diinginkan di kemudian harinya atau masa depan. Jika tidak terjadi kesamaan makna antara kedua aktor komunikasi, yakni komunikator dan komunikan itu, dengan lain perkataan komunikan tidak mengerti pesan yang diterimanya, maka komunikasi tidak terjadi. Dalam hal tersebut, situasi tidak komunikatif. Situasi komunikatif bisa terjadi seperti berupa pidato, ceramah, khotbah, dan lain-lain, baik komunikasi secara lisan maupun tulisan. Schramm menyatakan bahwa field of experience atau bidang pengalaman, merupakan faktor yang amat penting untuk terjadinya komunikasi.

Komunikasi menjadi sebuah unsur penting dalam keseharian manusia, untuk saling mengetahui satu sama lainnya, saling bertukar informasi yang dapat memenuhi kebutuhan pada kehidupan manusia. Menjadi sebuah urgensi yang sangat penting dalam keseharian manusia sebagai makhluk sosial, memberikan pengaruh secara menyeluruh dalam berkomunikasi, secara psikologis, sosial-budaya, ekonomi, dan pendidikan maupun perilaku.

Komunikasi merupakan aktifitas yang tidak terpisahkan dari keseharian manusia di berbagai bidang, termasuk dalam aktifitas politik. Berbagai fenomena modern menunjukan kepada kita, peran dan fungsi komunikasi politik yang semakin penting $^{1}$. Menurut Stewart L. Tubbs-Sylvia Moss komunikasi efektif merupakan keahlian terpenting, bahkan boleh jadi merupakan hal yang paling

\footnotetext{
${ }^{1}$ Heryanto. Gun Gun, Komunikasi Politik di Era Indonesia Citra, (Jakarta: PT Lasswell Vistiama, 2010), hal.3.
} 


\section{JURNAL TAMBORA}

Vol. 3 No. 1 Februari 2019

penting, untuk mencapai kebahagiaan dan keberhasilan hidup. ${ }^{2}$

Komunikasi politik sebagai kajian disiplin ilmu yang telah lama tercantum dalam kurikulum ilmu sosial, baik dalam kajian ilmu komunikasi maupun dalam kajian ilmu politik. Dengan komunikasi politik, para komunikator politik menyampaikan informasi yang memiliki unur-unsur politik, seperti halnya yang dilakukan oleh Pak Harto ketika suara mendehem yang membuat bawahannya ketakutan, sikap diam Megawati saat ditanya wartawan, yang menimbulkan berbagai penafsiran, dan baju kotakkotak yang dikenakan oleh Jokowi dan Ahok saat berkampanye dalam Pilkada DKI Jakarta tahun 2012, yang mengesankan kesederhanaan, kesederajatan dan kedekatan dengan rakyat, semua itu merupakan komunikasi politik yang disampaikan secara verbal ataupun non verbal. ${ }^{3}$ Komunikasi politik dapat diartikan proses komunikasi yang melibatkan pesan-pesan politik dalam setiap kegiatan-kegiatan kemasyarakatan, merujuk pada pengertian ini komunikasi politik mempunyai cakupan luas dalam setiap kegiatan kemasyarakatan. ${ }^{4}$

Tepat pada tanggal 9 Desember 2015, Pemilihan Kepala Daerah Bupati dan Wakil Bupati Kabupaten Sumbawa (Pilkada) di laksanakan pesta demokrasi masyarakat Kabupaten Sumbawa, sebagai ajang pemilihan kepala Daerah selanjutnya yang akan memimpin 5 (Lima) tahun ke depan Kabupaten Sumbawa.

Kampanye sebagai suatu proses penyampaian pesan kepada masyarakat atau komunikan di mana sumber pesan/informasi berasal dari komunikator yang menyampaikannya tersebut kepada masyarakat, memiliki tujuan tertentu yang harus dicapai dalam proses kampanye yang dilakukan secara pribadi/indisuvual, dan dilakukan secara terorganisir oleh suatu lembaga dan instansi yang memiliki tujuan-tujuan tertentu yang ingin dicapai dalam kampanye.

Adapun kampanye yang dilakukan oleh KPU Kabupaten Sumbawa yang terorganisir dan ingin mencapai tujuan tertentu dalam mengkampanyekan suatu hal dengan pola-pola komunikasi, kampanye sangatlah diperlukan dalam memberikan pengertian dan pendidikan Pilkada terhadap masyarakat

${ }^{2}$ Deddy Mulyana dan Gembirasari. Human Communication Konteks-Konteks Komunikasi.(Bandung: PT. Remaja Rosdakarya 2005) hal. $x$

${ }^{3}$ Prof. Deddy Mulyana, M.A., Ph.d., Komunikasi Politik, Politik Komunikasi. (Bandung: PT Remaja Rosdakarya 2013) hal.10.

${ }^{4}$ Maswardi Rauf., Komunikasi Politik: Masalah Sebuah Bidang Kajian dalam Ilmu Politik dalam Indonesia dan Komunikasi Politik, ed. Maswadi Rauf, Mappa Nasrun (Jakarta: Gramedia Pustaka Utama, 1993) hal. 3 sekitar. Maka dari itu KPU Kabupaten Sumbawa mempunyai tantangan besar dalam menyelenggarakan kampanye pada pelaksanaan Pilkada tahun 2015 dengan kondusif. Dari latar belakang masyarakat Kabupaten Sumbawa yang mempunyai perbedaan baik dari segi pendidikan, ekonomi, sosial dan pekerjaan, tentunya akan mempengaruhi pola fikir tingkat pemahaman yang berbeda pada masyarakat Kabupaten Sumbawa terhadap Pilkada.

Ditengah ketegangan dalam Pilkada tahun 2015 yang dilakukan secara serentak se-Nasional, upaya yang dilakukan oleh KPU Kabupaten Sumbawa dalam menciptakan suasana kampanye yang kondusif dalam pelaksanaan Pilkada Kabupaten Sumbawa 2015. Sehingga dalam penyelenggaraan kampanye Pilkada pada tahun 2015 yang diselenggarakan oleh KPU Kabupaten Sumbawa kepada masyarakat Kabupaten Sumbawa berlangsung dengan kondusif, tidak ada satupun pengajuan sengketa PHP (Perselisihan Hasil Pemilih) di Mahkamah Konstitusi dan tidak ada satupun yang mengajukan gugatan ke Mahkamah Konstitusi dari pasangan calon maupun dari masyarakat pasca pemungutan dan ditetapkannya rekapitulasi hasil perhitungan suara. ${ }^{5}$

Hal tersebut menjadi bagian salah satu dalam menciptakan susasana yang kondusif saat Pilkada berlangsung di Kabupaten Sumbawa, dan menjadi sebuah ciri khas tersendiri untuk KPU Kabupaten Sumbawa diantara daerah-daerah lain di Indonesia dalam kampanye upaya menciptakan suasana Pilkada Bupati dan Wakil Bupati Kabupaten Sumbawa yang kondusif, dan salah satu faktornya adalah pola komunikasi politik KPU Kabupaten Sumbawa dalam melaksanakan kampanye terhadap masyarakat Kabupaten Sumbawa, untuk menciptakan Pilkada Bupati dan Wakil Bupati Kabupaten Sumbawa yang Kondusif.

Dalam hal tersebut, Komisi Pemilihan Umum (KPU) Kabupaten Sumbawa sebagai lembaga penyelenggara Pilkada yang memiliki wewenang untuk menjalankan tugas dari pemerintah, berhasil dalam melaksanakan kampanye upaya menciptakan Pilkada Bupati dan Wakil Bupati Kabupaten Sumbawa tahun 2015 yang kondusif, dan juga tidak ada satupun sengketa PHP maupun gugatan di Mahkamah Konstitusi dari pasangan calon ataupun masyarakat dalam Pilkada Kabupaten Sumbawa tahun 2015. Salah satu kampanye yang diatur oleh Peraturan KPU No 7 Tahun 2015 adalah metode debat kandidat atau debat publik, dalam pelaksanaan debat publik yang dilaksanakan oleh KPU Kabupaten Sumbawa menjadi primadona dalam metode kampanye, setidaknya 3 (tiga) kali dilaksanakan dengan 3 (tiga) tempat pelaksanaan

${ }^{5} \mathrm{http}$ //kpud-ntbprov.go.id/berita-357-.html, diakses (pada 8 Januari 2017, pukul 21:05 WITA) 


\section{JURNAL TAMBORA}

Vol. 3 No. 1 Februari 2019

yang berbeda, dalam hal tersebut, KPU Kabupaten Sumbawa menjadi satu-satunya penyelenggara Pilkada di Indonesia dan salah satu KPU Kabupaten diantara 9 (sembilan) KPU Kabupaten/Kota di Propinsi Nusa Tenggara Barat yang melaksanakan debat publik di lapangan terbuka dan disaksikan oleh ribuan masyarakat, yang berlangsung dengan sukses, aman, damai, ramai dan meriah di tiga zona debat publik berlangsung. ${ }^{6}$

Begitupun pola-pola komunikasi politik yang dilakukan oleh KPU Kabupaten Sumbawa dalam upaya menciptakan Pilkada Bupati dan Wakil Bupati Kabupaten Sumbawa tahun 2015 yang kondusi, yaitu suksesnya pelaksanaannya dan aman.

Kondusif yang dimaksudkan dalam hal tersebut adalah, suksesnya terlaksananya Pilkada Bupati dan Wakil Bupati Kabupaten Sumbawa, dan juga terciptanya keamanan yang cukup memuaskan bagi pihak KPU Kabupaten Sumbawa, maupun dari pasangan calon dan masyarakat, yang di mana tidak ada kekerasan yang terjadi ketika Pilkada Bupati dan Wakil Bupati Kabupaten Sumbawa tahun 2015, sehingga, hal ini lah menjadi sebuah landasan terciptanya Pilkada Bupati dan Wakil Bupati yang kondusif tahun 2015.

Dalam penelitian ini, adapun tujuan penilitian yang dilakukan oleh peneliti yaitu untuk "Mengetahui pola komunikasi politik yang diterapkan oleh KPU Kabupaten Sumbawa dalam menghadapi Pilkada Bupati dan Wakil Bupati Kabupaten Sumbawa tahun 2015, sehingga pelaksanaan kampanye oleh KPU Kabupaten Sumbawa berjalan dengan kondusif".

\section{METODOLOGI}

Penelitian ini menggunakan metode penelitian deskriptif kualitatif. Menurut Bugdon dan Taylor, jenis penelitian deskriptif adalah berupaya menggambarkan kejadian dan fenomena sesuai dengan apa yang terjadi di lapangan dan data hasil berupa kata-kata tertulis dan lisan dari orang-orang, serta perilaku yang dapat diamati. ${ }^{7}$ Tujuan penelitian secara kualitatif deskriptif dalam penelitian ini yaitu untuk memberikan gambaran yang akurat, sistematis dan faktual sesuai dengan fakta-fakta tertentu dalam penelitian yang sedang dilakukan. Untuk pemilihan informan dengan cara proposive sampling, dalam penelitian ini membutuhkan 2 (dua) informan yang akan

\footnotetext{
${ }^{6} \mathrm{http}: / / \mathrm{kpud}-$

sumbawa.go.id/index.php/pic/pic/prdhkm20-9-

2016pengumuman\%20KPPD\%20yang\%20ikut $\% 2$

0diklat.pdf?node $=$ berita\&id $=179$, diakses (pada 19 Januari 2018, pukul 6:36 WITA)

${ }^{7}$ Miles B. Mathew dan Michael Huberman. Analisis Data Kualitatif Buku Sumber Tentang Metode-metode Baru.( Jakarta: UIP, 1992) hal.4
}

diwawancarai, dalam hal tersebut peneliti memilih Ketua KPU Kabupaten Sumbawa dan Ketua Divisi SDM dan Parmas KPU Kabupaten Sumbawa, proses pengumpulan data dalam penelitian ini adalah dengan observasi non-participant, in-depth interview, dan dokumentasi, selain itu proses analisis data dengan cara, reduksi, men-display data, verifikasi dan kesimpulan.

\section{HASIL DAN PEMBAHASAN}

Dalam kampanye yang dilakukan oleh KPU Kabupaten Sumbawa dalam upaya menciptakan susana yang kondusif pada Pilkada Bupati dan Wakil Bupati Kabupaten Sumbawa tahun 2015 menggunakan pola-pola komunikasi politik menurut Onong Uchdjana Effendi, yang di mana pola komunikasi politik terdiri dari, pola komunikasi politik satu arah, pola komunikasi politik dua arah dan pola komunikasi politik multi arah.

Adapun strategi-strategi yang dilakukan oleh KPU Kabupaten Sumbawa dalam kampanye pada Pilkada Bupati dan Wakil Bupati Kabupaten Sumbawa tahun 2015 sebagai berikut:

1. Pola Komunikasi Politik Satu Arah

Dalam pola komunikasi politik satu arah ini KPU Kabupaten Sumbawa melakukan berbagai startegi untuk mengkampanyekan para pasanan calon yang di usung oleh masing-masing partai atau koalisi, seperti melalui media cetak (baliho, spanduk, selembaran/flayer, brosur, umbul-umbul, koran), media online (e-news paper, facebook), media elektronik (radio). Dalam hal tersebut KPU Kabupaten Sumbawa berupaya untuk memberikan pemahaman juga pendidikan kepada masyarakat mengenai Pilkada Bupati dan Wakil Bupati Kabupaten Sumbawa, beserta para calon yang akan maju mengikuti ajang pemilihan Bupati dan Wakil Bupati Kabupaten Sumbawa tahun 2015. Isi pesan yang disampaikan oleh KPU Kabupaen Sumbawa bersifat politis, dalam hal ini komunikator menjadi peran utama dalam menyampaikan sebuah pesan yang akan disampaikan kepada komunikan, komunikator bersifat aktif sedangkan komunikan bersifat pasif/komunikan hanya menjadi pembaca dan pendengar saja, tidak terjadi feed back secara langsung antara komunikator dengan komunikan, pesan yang disampaikan oleh komunikator melalui media perantara seperti, media cetak, media online dan media elektronik.

2. Pola Komunikasi Politik Dua Arah

Dalam pola komunikasi politik dua arah ini KPU Kabupaten Sumbawa melakukan berbagai strategi seperti deklarasi kampanye damai, deklarasi kampanye damai yang dilaksanakan oleh KPU Kabupaten Sumbawa dalam upaya untuk mengajak dari setiap pasangan calon dan tim kampanye setiap pasangan calon untuk berupaya menciptakan kampanye yang kondusif, yang tidak terjadi kekerasan yang berakibat fatal dan 


\section{JURNAL TAMBORA}

Vol. 3 No. 1 Februari 2019

menimbulkan kegaduhan dalam Pilkada Bupati dan Wakil Bupati Kabupaten Sumbawa tahun 2015 terhambat.

Pola komunikasi dua arah yang dilakukan oleh KPU Kabupaten Sumbawa memiliki timbal balik secara langsung, baik tidak disadari maupun disadari, komunikator utama pada hakekatnya menjadi aktor utama dalam penyampaian pesan/informasi kepada masyarakat, dalam hal tersebut yang dilakukan oleh KPU Kabupaten Sumbawa dalam melakukan kampanye dengan pola komunikasi dua arah adalah pelaksanaan deklarasi damai, tujuan dalam deklarasi tersebut adalah, dari setiap pasangan calon maupun tim kampanye dari setiap pasangan calon berkomitmen untuk menjaga keamanan, mematuhi peraturan UndanganUandang yang telah berlaku dalam pelaksanaan Pilkada Bupati dan Wakil Bupati, serta siap dalam menerima hasil dari perhitungan suara akhir, dan siap atau tidak akan menerima terpilih atau tidak terpilihnya ketika hasil sudah di umumkankan.

3. Pola Komunikasi Multi Arah

Pola komunikasi politik multi arah menjadi salah satu dari bagian pola komunikasi yang dilakukan oleh KPU Kabupaten Sumbawa, pola komunikasi yang dibentuk secara dialogis, adapun produk kampanye yang dilakukan oleh KPU Kabupaten Sumbawa dan penliti menggolongkan sebagai pola komunikasi politik multi arah yaitu Debat Kandidat/Debat Publik yang dilaksanakan oleh KPU Kabupaten Sumbawa secara terbuka di lapangan, dan dapat dihadiri oleh berbagai kelompok masyarakat, dari perbedaan usia, perbedaan profesi, dan lain-lain, sehingga seluruh masyarakat dapat meyaksikan kegiatan kampanye yang dilakukan oleh KPU Kabupaten Sumbawa tersebut.

Debat publik yang dilaksanakan oleh KPU Kabupaten Sumbawa memiliki tujuan untuk mengkampanyekan para calon Bupati dan Wakil Bupati Kabupaten Sumbawa kepada masyarakat, agar masyarakat dapat mengetahui kriteria-kriteria pemimpin atau calon yang akan dipilihnya ketika menjelang hari pemilihan tiba.

Pola komunikasi politik multi arah yang dilakukan dalam kegiatan berkampanye oleh KPU Kabupaten Sumbawa ini tidak hanya melibatkan interaksi dinamis antara moderator dan pasangan calon yang berada di atas panggung, juga melibatkan interaksi yang dinamis antara masyarakat dengan masyarakat lainnya yang sedang menyaksikan secara langsung kegiatan debat publik.

Pola komunikasi politik KPU Kabupaten Sumbawa dalam kegiatan berkampanye oleh KPU Kabupaten Sumbawa memiliki keunikan tersendiri yang menjadi ciri khas yang dimiliki dan dilakukan dalam pengaplikasiannya ketika kampanye yang dilakukan oleh KPU Kabupaten Sumbawa dalam Pemilihan Bupati dan Wakil Bupati Kabupaten
Sumbawa Tahun 2015, yaitu Pola Komunikasi Budaya yang dilakukan oleh KPU Kabupaten Sumbawa.

Dalam hal pelaksanaan debat publik yang di selenggarakan oleh KPU Kabupaten Sumbawa, memiliki susasana yang berbeda, yang di mana budaya asli Sumbawa disatukan dalam pelaksanaan debat publik tersebut, seperti halnya ketika Ketua KPU Kabupaten Sumbawa memiliki kesempatan untuk menyampaikan pepatah kata atau mukoddimah dalam pelaksanaan debat publik akan berlangsung, Ketua KPU Kabupaten Sumbawa selalu memberikan pepatah kata dengan bahasa Sumbawa, dalam menjaga sebuah kondusifitas ketika berlangsungnya debat publik, dan menumbuhkan kembali budaya-budaya Sumbawa, tidak hanya melalui komunikasi secara verbal, adapun komunikasi secara non verbal yang dicampur dengan budaya-budaya Sumbawa yang dimiliki, seperti halnya dekorasi panggung pelaksanaan debat publik berlangsung ketika di Kecamatan Plampang, dan tradisi-tradisi budaya Sumbawa yang diterapkan oleh KPU Kabupaten Sumbawa sebelum pelaksanaan debat publik yang ke-tiga berlangsung, juga pakaian dari Ketua KPU Kabupaten Sumbawa beserta lima anggota komisioner KPU Kabupaten Sumbawa menggunakan pakaian adat ketika pelaksanaan debat publik berlangsung di Kecamatan Plampang.

Oleh karena itu, hal tersebut menjadi sebuah keunikan maupun inovasi terbaru dan berbeda yang dimiliki oleh KPU Kabupaten Sumbawa dengan KPU Kabupaten/Kota yang tersebar di Propinsi Nusa Tenggara Barat dalam penyelenggaraan Pilkada Bupati dan Wakil Bupati Tahun 2015, khususnya dalam pelaksanaan debat publik/debat kandidat berlangsung.

\section{PENUTUP}

\section{Kesimpulan}

Berdasarkan penelitian yang dilakukan oleh penulis tentang Pola Komunikasi Politik KPU Kabupaten Sumbawa dalam Menghadapi Pilkada Bupati dan Wakil Bupati Kabupaten Sumbawa Tahun 2015, studi kasusnya adalah Kampanye oleh KPU Kabupaten Sumbawa dalam upaya menciptakan Pilkada Bupati dan Wakil Bupati Kabupaten Sumbawa tahun 2015 yang kondusif yang dihubungkan dengan tujuan penelitian, maka penulis mengambil kesimpulan bahwasanya, pola komunikasi yang dipaparkan dalam teori Onong Uchdjana Effendi memiliki peran penting dalam tercipnya kondusifitas pada kampanye Pilkada Bupati dan Wakil Bupati Kabupaten Sumbawa tahun 2015 oleh KPU Kabupaten Sumbawa.

Pola-pola komunikasi yang diterapkan oleh KPU Kabupaten Sumbawa memiliki dampak terhadap pelaksanaan kampanye Pilkada Bupati dan Wakil Bupati Kabupaten Sumbawa tahun 2015 oleh KPU Kabupaten Sumbawa, sehingga 


\section{JURNAL TAMBORA}

\section{Vol. 3 No. 1 Februari 2019}

kondusifitas dalam pelaksanaannya, KPU Kabupaten Sumbawa menjadi salah satu diantara KPU Kabupaten/Kota yang tersebar di Propinsi Nusa Tenggara Barat yang berhasil menciptakan suasana yang kondusif dalam pelaksanaan Pilkada Bupati dan Wakil Bupati Kabupaten Sumbawa tahun 2015, tidak terjadinya sebuah permasalahan yang begitu signifikan sehingga menghambat pelaksanaan Pilkada Bupati dan Wakil Bupati tahun 2015, ini menjadi sebuah prestasi dan apresiasi yang dimiliki oleh KPU Kabupaten Sumbawa dalam pelaksanaan Pilkada Bupati dan Wakil Bupati tahun 2015.

KPU Kabupaten Sumbawa juga memiliki keunikan tersendiri dalam pelaksanaan kampanye oleh KPU Kabupaten Sumbawa dalam menghadapi Pilkada Bupati dan Wakil Bupati Kabupaten Sumbawa tahun 2015, yaitu pola komunikasi budaya yang terapkan dalam pelaksanaan kampanye oleh KPU Kabupaten Sumbawa, pola komunikasi budaya yang dilakukan oleh KPU Kabupaten Sumbawa secara verbal maupun non verbal memberikan dampak yang positif terhadap pelaksanaan kampanye oleh KPU Kabupaten Sumbawa dalam menghadapi Pilkada Bupati dan Wakil Bupati Kabupaten Sumbawa tahun 2015, dalam hal tersebut menjadi sebuah keunikan yang dimiliki oleh KPU Kabupaten Sumbawa dalam mengkampanyekan semua pasangan calon dengan waktu yang bersamaan dan tempat yang bersamaan.

Oleh karena itu KPU Kabupaten Sumbawa berhasil dalam menciptakan Pilkada Bupati dan Wakil Bupati Kabupaten Sumbawa tahun 2015 yang kondusif, dengan menggunakan pola-pola komunikasi yang disampaikan menurut Onong Uchdjana Effendi dan pola komunikasi budaya yang terapkan oleh KPU Kabupaten Sumbawa.

\section{Saran}

1. Dapat tetap menggunakan pola komunikasi menurut Onong Uchdjana Effendi yaitu pola komunikasi satu arah, pola komunikasi dua arah, dan pola komunikasi multi arah dalam kampanye Pilkada Bupati dan Wakil Bupati oleh KPU Kabupaten Sumbawa, sehingga terciptanya suasana yang kondusif saat menghadapi Pilkada.

2. Penelitian ini sebagai bahan referensi KPU Kabupaten Sumbawa dalam berkampanye menggunakan pola komunikasi yang telah dijelaskan dalam penilitian ini, yang meruju terhadap teori menurut Onong Uchdjana Effendi tentang teori pola-pola komunikasi.

\section{REFERENSI}

Heryanto. Gun Gun, Komunikasi Politik di Era Indonesia Citra, (Jakarta: PT Lasswell Vistiama, 2010)

Mulyana, Deddy., dan Gembirasari. Human Communication Konteks-Konteks Komunikasi.(Bandung: PT. Remaja Rosdakarya 2005)

Mulyana, Prof, Deddy. Komunikasi Politik, Politik Komunikasi. (Bandung: PT Remaja Rosdakarya 2013)

Maswardi Rauf., Komunikasi Politik: Masalah Sebuah Bidang Kajian dalam Ilmu Politik dalam Indonesia dan Komunikasi Politik, ed. Maswadi Rauf, Mappa Nasrun (Jakarta: Gramedia Pustaka Utama, 1993)

Mathew, Miles, B., dan Huberman, Michael. Analisis Data Kualitatif Buku Sumber Tentang Metode-metode Baru.( Jakarta: UIP, 1992)

http://kpud-ntbprov.go.id, diakses (pada 8 Januari 2017, pukul 21:05 WITA)

http://kpud-sumbawa.go.id, diakses (pada 19 Januari 2018, pukul 6:36 WITA) 